Chemistry, to which reference has already been made in these columns (Jan. 14, p. 53). Two general discussions will be held on Oct. 16-22, on "The Electron Theory of Metals" and on "Electrolytes and Boundary Layers (Electrode-Solution)". Among those who have already promised contributions to the discussions are Prof. Brillouin (Paris), F. Bloch (Leipzig), Prof. V. Henri (Liège), Prof. Joffé (Leningrad), Prof. E. K. Rideal (Cambridge), Prof. M. Volmer (Berlin), Prof. P. Debye (Leipzig), Prof. P. Dutoit (Lausanne), R. Audubert (Paris), Prof. F. Dubois (Clermont-Ferrand), A. H. Wilson (Cambridge), Prof. A. Gillet (Liège), Prof. O. Scarpa (Milan), Prof. Denina (Turin), Prof. J. Heyrovský (Prague). Notification of proposed attendance at the meeting should be sent as early as possible to the General Secretary of the Society, Dr. Ch. Marie, 9 rue de Bagneux, Paris (VI). The registration fee is 125 francs, including reception, banquet, excursions, etc., as well as advance copies of papers for discussion. Advance proofs will be forwarded immediately to those who pay their registration fee before June 30 ; others will receive them at the meeting in October.

\section{Sixth Imperial Social Hygiene Congress}

The sixth Imperial Social Hygiene Congress will be held at the London School of Hygiene and Tropical Medicine, Keppel Street, London, W.C.1 on July 3-7 under the presidency of Sir Basil Blackett. On July 3 , the presidential address will be delivered, and the rest of the Congress will be divided into a series of discussions including such topics as the effect on established social customs of modern knowledge and economic conditions; changes in the outlook on prostitution; biology and health - the teaching of biology in schools and colleges ; conference of teachers of biology ; methods of dealing with venereal disease in the defence forces of different nations; the training, etc., of health visitors, nurses and midwives; venereal disease administration and the supply of educational and cultural films. Progress reports from Great Britain and the Dominions concerning different branches of social hygiene will be presented at the Congress. Arrangements have been made for visits to various institutions of interest to the delegates, a special display of films, and an exhibition of simple equipment used in biological teaching. Further information concerning the Congress can be obtained from the Secretary, British Social Hygiene Council, Carteret House, Carteret Street, London, S.W.1.

\section{Announcements}

Aт a meeting of the Royal Society held on May 25, the following were elected foreign members of the Society : Prof. Vilhelm Friman Koron Bjerknes, of the Physical Institute of the University of Oslo; Prof. Harvey Williams Cushing, of New York, distinguished for his work on the surgery of the brain; Prof. Peter Debye, professor of physics in the University of Leipzig; Prof. Friedrich August Ferdinand Christian Went, professor of general botany in the University of Utrecht.
THE annual visitation of the National Physical Laboratory will take place on June 27 from 3 to 6 p.m.

The Right Hon. Lord MrLchetr has consented to accept the presidency of the British Science Guild in succession to the Right Hon. Sir Samuel Hoare, whose three-year term of office ends this month. Lord Melchett will be elected president of the Guild at the annual general meeting to be held in the Mansion House on June 19 at 4.30 p.m. when the Right Hon. The Lord Mayor of London (Sir Percy W. Greenaway) has kindly agreed to take the chair.

AT the anniversary meeting of the Linnean Society of London held on May 24 the following were elected officers of the Society:-President, Prof. F. E. Weiss; Treasurer, Mr. Francis Druce; Botanical Secretary, Mr. John Ramabbottom; Zoological Secretary, Dr. Stanley W. Kemp.

THE annual general meeting of the British Science Guild will be held in the Mansion House, London, E.C.4, on June 19, at 4.30 p.m., when the chair will be taken by the Right Hon. the Lord Mayor of London. The meeting will be followed by a popular lecture entitled, "Some Problems of British Forestry", by Prof. R. S. Troup, professor of forestry in the University of Oxford and director of the Imperial Forestry Institute.

Appuicatrons are invited for the following appointments on or before the dates mentioned :-An assistant lecturer in mathematics at the University College of South Wales and Monmouthshire-The Registrar, University College, Cardiff (June 12). A director of research at the Forest Products Research Laboratory, Princes Risborough-The Secretary, Department of Scientific and Industrial Research, 16, Old Queen Street, Westminster, S.W.1 (June 22). A lecturer in pathology at the University of LiverpoolThe Registrar (June 24). A head of the Manual Training and Engineering Department of Christ's Hospital, Horsham-The Headmaster. An assistant lecturer in agricultural botany at the University of Reading-The Registrar. A part-time teacher of bakery science (especially elementary physics and chemistry) at the Borough Polytechnic, London, S.E.1-The Principal. A head of the Mining Department at the County Technical College, Mansfield-The Principal. A lecturer in biology and some mathematics at the Stockwell Training College, London, S.W.9-The Principal. External examiners in scientific, medical and other subjects for various degree examinations in the University of LondonThe External Registrar, University of London, South Kensington, S.W.7 (July 3).

Erratum.-In Nature of May 27, p. 764, twelve lines from foot of first column, for " $n n$ higher unstable and lower grades" read "unstable $n n$ higher and lower grades". 